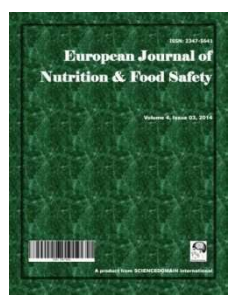

European Journal of Nutrition \& Food Safety

6(1): 12-35, 2016, Article no.EJNFS.2016.003

ISSN: 2347-5641

SCIENCEDOMAIN international

www.sciencedomain.org

\title{
Supplements in the European Union: An Analysis of Health Claims Related to Articular Joint Health
}

\author{
Madalena Bettencourt-Câmara ${ }^{1,2}$, Bruno Sepodes ${ }^{2}$, Rosário Bronze ${ }^{2,3}$ \\ and Maria-Eduardo Figueira ${ }^{2^{\star}}$
}

${ }^{1}$ Center for Interdisciplinary Research Egas Moniz, CiiEM, Egas Moniz Cooperativa de Ensino

Superior CRL, Monte de Caparica, Portugal.

${ }^{2}$ Faculdade de Farmácia da Universidade de Lisboa, Avenida Professor Gama Pinto, 1649-003 Lisboa, Portugal.

${ }^{3}$ Instituto de Tecnologia Química e Biológica, Av. da República, 2780-157 Oeiras, Portugal.

\begin{abstract}
Authors' contributions
This work was carried out in collaboration between all authors. Author MBC designed the review, performed the analysis, managed the literature searches, and wrote the first draft of the manuscript.

Authors BS and MEF managed the analyses of the study and worked on the first draft and final version of the manuscript. All authors read and approved the final manuscript.
\end{abstract}

Article Information

DOI: 10.9734/EJNFS/2016/19031

Review Article

Received 22 ${ }^{\text {nd }}$ May 2015

Accepted $31^{\text {st }}$ August 2015

Published $16^{\text {th }}$ September 2015

\section{ABSTRACT}

In the European Union, amino acids, enzymes, pre- and probiotics, essential fatty acids, botanicals and botanical extracts and miscellaneous bioactive substances can be marketed as food supplements (FS). Food supplements that are meant to benefit human health contain claims on their label stating their benefits. Since 2007, health claims made on FS, are prohibited unless they are authorized and included in the EU Register of Nutrition and Health Claims on Food (the EU Register), in accordance with the requirements of Regulation (EC) $n^{\circ}$ 1924/2006.

Aims: This manuscript reviews the evidence required to support health claims made on FS considering the legal framework of these foodstuffs and, as a case study, analyses the health claims on articular joint health included in the EU Register. The EFSA scientific opinions related to those health claims have also been considered. In EU, some botanicals and miscellaneous bioactive substances can be marketed as medicinal or as food supplements. The regulatory issues on botanicals and the debate on how to create a regulatory framework for botanicals is mentioned. Results: By April 2015, 77 functional health claims on joints health were included in the EU Register. The status of all these claims was non-authorised. The great majority were Article 13.1 claims $(91 \%)$. All functional claims related to articular joints function were made on target functional ingredients, mainly other substances that could be used in the manufacturing of FS. Human trials

*Corresponding author: Email: efigueira@ff.ulisboa.pt; 
conducted in diseased population were the main statement from EFSA for the non-approval of the health claims on articular joints. Criteria and more guidance addressing methodological issues on human trials would benefit future applications and scientific research.

Conclusion: Legal issues regarding other substances than vitamins and minerals, namely botanical ingredients should also be taken in account in future FS health claims on articular joints. On this subject, efforts to improve the existing regulatory framework, namely with regard to botanicals products could also benefit future FS health claims.

Keywords: Food supplements; health claims; health outcomes; EFSA; articular joint; rheumatoid arthritis.

\section{INTRODUCTION}

The political, socioeconomic and technological developments in Europe and other developed countries since the 1960's made a more secure and abundant global food supply possible. This was an important factor in the increase in life expectancy. On the other hand, changes in diet, high stress levels and the prevalence of more sedentary lifestyles that are characteristic of developed societies had significant negative impacts in the health of the populations. In recent years the prevalence of chronic noncommunicable diseases (NCDs) has increased dramatically. In 2012, 38 million people died from NCDs [1]. Chronic diseases, such as obesity, diabetes mellitus and rheumatoid arthritis (RA), also cause high morbidity and disability, with serious social consequences and significant economic implications for the health of several countries systems $[1,2]$. Considering these facts a new paradigm, focused on the prevention of disease and in the promotion of people's wellbeing, is emerging $[3,4,5]$.

RA is a chronic systemic autoimmune disease, a multi articular syndrome of unknown cause, which is characterized by a persistent synovitis, synovial hyperplasia and inflammatory cell infiltration, presence of auto-antibodies and progressive destruction of cartilage and bone $[6,7,8]$. Studies made in European and North America countries estimate a prevalence RA 0.5$1 \%$ and an average annual incidence of 0.02 $0.05 \%$ [9]. RA is associated with inflammation and progressive erosion of the joints leading often to loss of functionality, severe morbidity and premature mortality [10]. The deformations in synovial joints, especially small joints of the hands and wrists, symmetrically, lead to a limited range of motion. In the first year of disease onset about $70 \%$ of patients suffer irreversible joint destruction and approximately $80 \%$ of working age adults, experience disabling pain, stiffness and reduced functional capacity, with high costs for individuals and society [10]. In this context and given the global economic situation, research of anti-arthritic effects in food, food ingredients and / or extracts seems very interesting and important in terms of health outcomes.

In the EU countries, plant preparations with pharmacological activity can be marketed as pharmaceutical products or as food supplements. Contemporary lifestyle issues, namely low nutrient density diet, lack of exercise and high levels of stress, created an opportunity for the food supplements market to growth. Food supplements are commonly used for health purposes and therefore are labelled with health claims indicating its benefits. In the EU market, the use of health claims made on food supplements is regulated under Regulation (EC) no1924/2006, which imposes that only authorized claims, included in the EU Register, can be used in food.

It is well established that plant preparations contain different biologically active compounds, many of them with a physiological effect in humans or even therapeutic [11]. The red raspberry (Rubus idaeus L.) fruit contains several nutrients (fiber, ascorbic acid and folates) and substances (bioactive phenolic compounds, mainly ellagitannins and anthocyanins) of pharmacological interest [12]. In a recent study, Figueira et al. [13] demonstrated the antiinflammatory effects of a red raspberry fruit extract rich in phenolic compounds, in a collagen-induced arthritis rat model. The authors suggested that red raspberry extracts with pharmaceutical activity could potentially be used as a dietary source of pharmacologically active compounds that may have an active role in delaying the progression of inflammatory articular injury associated with arthritic conditions.

This article reviews the evidence required to support health claims made on food supplements, considering the legal framework of 
this foodstuffs. The regulatory standpoint of health benefit for health joints is approached through an analysis of the Commission's authorized and non authorized health claims made on foods and the published opinions of the Panel on Dietetic Products, Nutrition and Allergies (NDA) of the European Food Safety Authority (EFSA) on health claims applications. A special focus is given to health claims concerning articular joints.

\section{METHODOLOGY}

A literature search was conducted using online databases: Eur-Lex

http://eur-lex.europa.eu/advanced-search

form.html for the legal framework; EFSA (http://www.efsa.europa.eu/en/nda/ndaguidelines .htm and

http://www.efsa.europa.eu/en/nda/ndascdocs.ht $\mathrm{m}$, accessed April 2, 2015) for both guidelines on health claims and scientific opinions concerning health claims applications; the 'EU Register of Nutrition and Health Claims' (http://ec.europa.eu/nuhclaims/, accessed April $2,2015)$ for all the Commission's authorized and non authorized health claim on foods related to joints. The Pubmed and B-on online databases were also used to retrieve publications considered in EFSA opinions for substantiation health claims concerning health benefits related to joints. Finally, health claims opinions published by EFSA regarding others health benefits were included for comparison purposes.

\section{RESULTS AND DISCUSSION}

\subsection{Results}

\subsubsection{Legal framework}

An overview of EU legislation relevant to food supplements and health claims on these products is summarized in Table 1.

Food supplements are foodstuffs intended to supplement a normal diet. Food supplements (FS) are regulated in the UE under the Directive 2002/46/EC (FSD) [14], implemented in Portugal into the Decreto-Lei no $136 / 2003$ of 28 July [15]. According to those acts, FS are concentrated sources of vitamins, minerals or other substances with a nutritional or physiological effect, taken alone or in combination, marketed in dose form (capsules, pastilles, tablets, pills, sachets of powder, ampoules of liquids, drop dispensing bottles, among others similar forms designed to be taken in measured small unit quantities). FSD and amended acts lays down a harmonised list of 30 vitamins and minerals (Annex I) that can be added for nutritional purposes in these foodstuffs and a list of 175 permitted sources of vitamins and minerals (Annex II) from which FS can be manufactured.

As foodstuff, all FS introduced in the EU market shall meet all requirements outlined in the General Food Law, in particular with regard to food safety [16]. Considering the food law definition and the food safety requirements set out in the Regulation (EC) $\mathrm{n}^{0}$ 178/2002 (general food law), FS traded in EU market shall comply with the relevant laws, regulations and administrative provisions governing food safety, whether at Community or national level, including those relating to food information and nutrition (namely nutrition and health claims [17] and food for specific groups), food improvement agents (food additives, food enzymes and food flavourings), chemical safety (contaminants, residues, pesticides and extraction solvents), biological safety (including food hygiene and irradiation), novel food [18]. The Regulation (EC) no 1925/2006 [19] regarding the food fortification contains a procedure (Articles 8) to cover situations where safety issues could arise with the addition of other substances to food supplements or used in the manufacture of such foodstuffs, namely botanical ingredients. However, the provisions of that Regulation regarding vitamins and minerals shall not apply to food supplements covered by FSD.

Novel FS or FS containing novel ingredients (not present at a significant degree on the EU market before May 15, 1997) shall also meet the requirements of the Regulation (EC) no 258/1997 [20] concerning novel foods and novel food ingredients. According to that act, those novel FS or the novel ingredients, e.g. botanical ingredients used in its composition must be safe for the consumers and properly labelled to not mislead consumers. Unlike FS/ingredients presents at a significant degree on the EU market before May 15, 1997, marketing a novel FS or a novel ingredient requires prior authorisation as referred to in Regulation (EC) no 258/1997. Companies shall first apply to the EU National Authority, in which the product will be marketed, presenting the scientific information and safety assessment report. 
Table 1. Overview of EU legislation relevant to food supplements and health claims

\begin{tabular}{l}
\hline Legislation \\
\hline Reg 178/2002 of the \\
European Parliament and \\
Council \\
\\
Dir 2002/46 of the \\
European Parliament and \\
Council (as amended by \\
Dir 2006/37, Reg \\
1137/2008, Reg \\
1170/2009,Reg \\
1161/2011; Reg \\
119/2014; Reg 2015/414) \\
Reg 258/97 of the \\
European Parliament and \\
Council \\
(under revision; as \\
amended by Reg \\
1829/2003, Reg \\
1882/2003, \\
Reg 1332/2008,Reg \\
596/2009) \\
Reg 1924/2006 of the
\end{tabular}

$\begin{array}{ll}\text { Topic } & \text { Relevance } \\ \text { General food law } & \begin{array}{l}\text { General principles and } \\ \text { requirements of food legislation } \\ \text { and in matters of Food safety to } \\ \text { be taken into account. Sets the } \\ \text { procedures governing EFSA's } \\ \text { operation }\end{array} \\ \text { Food } & \text { Establishes specific rules for the } \\ \text { supplements } & \begin{array}{l}\text { labelling and on vitamins and } \\ \text { minerals in food supplements }\end{array}\end{array}$

References

OJ L31, 1.2.2002, p.1

Novel food/Novel Establishes the rules for prefood ingredients market authorisation procedure for new and innovative food (ingredients) which have not been used for human consumption to a significant degree within the EU before 15 May 1997

European Parliament and Council

(as amended by Reg

107/2008, Reg 109/2008,

Reg 116/2010,Reg

$1169 / 2011$,

Reg1047/2012;

$\operatorname{Reg}$ 907/2013)

Reg 1925/2006 of the

European Parliament and

Council

(as amended by Reg

108/2008)

Nutrition and food

Addition of vitamins and minerals and of certain other substances to food

Health claims on food

Reg 353/2008 of the
European Parliament and Council

(as amended by Reg

1169/2009)

Reg 764/2008 of the

European Parliament and Council

$\operatorname{Reg} 1169 / 2011$ of the European Parliament and Council

(as amended by Reg

$1155 / 2013$

Reg 78/2014)

Free movement of food in the Internal Market

Food information to consumers health claims on

Establishes the basic principles and requirements about Nutrition and health claims on food and food supplements; sets the authorisation procedure

Provisions of this Regulation regarding vitamins and minerals shall not apply to food supplements. However, this act contains a procedure to cover situations where safety issues could arise with the addition of other substances to food supplements or used in the manufacture of such foodstuffs, namely botanical ingredients

Establishes the basic law and requirements on nutrition and health claims on food, namely the authorisation procedure
Sets the procedures relating to the application of certain national technical rules to products lawfully marketed in another Member State

Establishes general Food information requirements, mandatory Food information, including nutrition declaration, distance selling, voluntary food information and requirements about national measures
OJ L183, 12.7.2002,p.51

(OJ L94, 1.4.2006, p.32;

OJ L311, 21.11.2008,

p.1; OJ L314, 1.12.2009, p.36; OJ L296,

15.11.2011, p.29; OJ

L39, 8.2.2014, p.44; OJ

L68, 13.3.2015, p.26)

OJ L183, 12.7.2002,p.51

(OJ L94, 1.4.2006, p.32;

Corrigendum, OJ L12,

18.1.2007,p.3 (OJ L39,

13.2.2008, p.8; OJ L39,

13.2.2008, p.14; OJ L37, 10.2.2010, p.16;

Corrigendum, OJ L247, 13.9.2012,p.17; OJ L310, 9.11.2012, p.36; OJ 251, 21.9 .2013 , p. 7)

OJ L404,30.12.2006, p.26 (OJ L39, 13.2.2008, p.8)

OJ L109,19.4.2008,p.11 (OJ L314, 1.12.2009, p.34)

OJ L218, 13.08.2008, p.21

Corrigendum, OJ L247, 13.9.2012,p.17 (OJ L306, 16.11.2013, p.7; OJ L27, 30.1.2014, p.7; OJ L37, 10.2.2010, p.) 
The implementation of FSD with rules concerning certain aspects of vitamins and minerals has been an important key step to harmonise the regulation of FS across the EU. However, the use of substances with nutritional or physiological effects, other than vitamins and minerals, in FS is not yet harmonised. For these aspects national rules remain applicable and the national authorities shall apply the principle of mutual recognition to FS lawfully marketed in other EU member states (articles 34/36 of the EU Treaty) [21]. The Mutual Recognition Principle, as laid down in article 28 of the Treaty on the Functioning of the European Union (TFEU) relating to the prohibition of quantitative restrictions between Member States, is an important instrument for facilitating the free movement of those FS within the EU market [22, 23]. According to this principle, unless it can be shown that there is a danger for human health, Member States are not allowed to prohibit, restrict or impose administrative procedures of equivalent effect, on imports of FS of another Member State if the FS is lawfully produced or marketed in the exporting Member State [23]. The Mutual Recognition Regulation (Regulation (CE) $n^{\circ}$ 764/2008), defines the rights and obligations of national competent authorities and those of enterprises wishing to sell in a Member State products lawfully marketed in another Member State, when the authorities intend to take restrictive measures regarding the product in accordance with their national technical rules [23,24]. This act, applicable since 13 May 2009, focuses in particular on the burden of proof by setting out the procedural requirements for denying mutual recognition [23,24].

The FSD gives a broad definition of FS to include non-vitamin and mineral ingredients but does not specifies categories for those ingredients [14]. As there are no legal specifications regarding 'other substances with a nutritional or physiological effect' in the present work we will adopt the classification proposed by the European Advisory Services in a report for the European Commission, in 2007 [25]. According to the European Advisory Services 'other substances with a nutritional or physiological effect' are 'botanicals' (herbs, plants, fungi, algae and extracts thereof) and 'other bioactive substances' [25]. This last term refers to any substance with a nutritional or physiological effect, other than vitamins, minerals and botanicals, namely amino acids, enzymes, pre- and probiotics, essential fatty acids and miscellaneous bioactive substances [25]. This classification was based: (i) on the substances other than vitamins and minerals found in the UE FS market; (ii) on well established biochemical classes of molecules; (iii) the nature and origin of the these substances [25]. Recently in this year EFSA NDA Panel.

\subsubsection{FS and health claims}

FS are generally designed to improve and/or maintain human health. Frequently, these foodstuffs contain claims on their label stating those benefits [26]. However, health claims on FS shall only be permitted if the nutrient or the substance in respect of which the claim has been made show to have a beneficial physiological effect [17]. The Regulation (UE) no 1924/2006 distinguishes two categories of claims: nutrition claims (Article 8) and health claims (Articles 13 and 14). According the Regulation (EC) $n^{-}$ 1924/2006 [17], health claims on FS are statements that imply that a relationship exist between a FS category, a FS or one of its constituents and a health condition $[17,26]$. There are four types of health claims (Fig. 1): functional claims, generic or based on new evidence, with or without proprietary data protection (Article 13.1 and Article 13.5, respectively) or claims regarding disease risk reduction (Article 14.1.a) or children development or health (Article 14.1.b) [17]. General function claims deals mainly with claims describing or referring to the role of a nutrient or other substance in growth, development and functions of the body; or psychological and behavioural functions; or, without prejudice to Regulation (EU) no 609/2013 [27], slimming or weight-control or a reduction in the sense of hunger or an increase in the sense of satiety or to the reduction of the available energy from the diet'. Those claims have been submitted until January 2008, through the competent authorities of different Member States. New function claims are 'based on newly developed scientific evidence and/or which include a request for the protection of proprietary data'. Finally, reduction of risk claims are health claims that 'states, suggests or implies that the consumption of a food category, a food or one of its constituents significantly reduces a risk factor in the development of a human disease'. In EU, claims for the prevention, treatment or cure of human disease (medical claims) are reserved for medical products [28].

Unlike general functional claims that are based on 'generally accepted scientific evidence', Article 13.5 and Article 14 health claims require prior authorisation and a submission of an extensive dossier with the scientific data (see 
Table 2 for an overview of key requirements for these health claims on food supplements). The implementing rules for applications for authorisation of health claims as provided for in Article 15 of Regulation (EC) no 1924/2006 has been established in the Regulation (EC) $\mathrm{n}^{-}$ 315/2008 [29]. The dossier provided by the applicant shall demonstrate that [29]: the claimed effect of the FS is 'beneficial for human health'; 'a cause and effect relationship is established' between consumption of the FS and the claimed effect in humans (such as the strength, consistency, specificity, dose-response, and biological plausibility of the relationship); the quantity of the FS and 'pattern of consumption required to obtain the claimed effect could reasonably be achieved as part of a balanced diet'; 'the specific study group(s) in which the evidence was obtained is representative of the target population for which the claim is intended'.

According to Regulation (EC) no 353/2008 [29], the applicant must provide all the available data (including data published and unpublished, in favour and not in favour) that are pertinent to the proposed health claim, together with a comprehensive review of the data from human studies, demonstrating that the heath claim is substantiated, in a stand-alone dossier. Each application must cover only one relationship between a FS or constituent (nutrient or other substance), and a single claimed effect. Scientific data in the dossier shall consist primarily of studies in humans (human intervention and observational studies and other human studies dealing with the mechanisms by which the FS could be responsible for the claimed effect, namely studies on bioavailability) followed by non-human data, animal data and ex vivo or in vivo data (e.g. mechanistic studies), when appropriate. Randomized controlled human studies (RCT) are, among the human intervention studies those that can generate the strongest scientific evidence.

EFSA (particularly NDA Panel) assesses the scientific substantiation of all applications for health claims from EU Member States [17]. Under this work EFSA NDA Panel has conducted several consultations and published scientific advice and technical guidance to assist applicants in the preparation of applications for the authorisations of health claims [30]: general guidance on how to submit claims [31,32] and specific guidance on scientific requirements for health claims related to some beneficial physiological health effects to human health (see Table 3 for an overview of EFSA's relevant guidance for FS health claims on joints). In general terms, the criteria used by the EFSA NDA Panel for the assessment procedure of health claims have been the following [32]: $(I)$ the food/food supplement or food ingredient is defined and characterized; (ii) the claimed effect is defined and the claimed effect is a beneficial physiological effect; (iii) A cause and effect relationship is established between the consumption of the food/food supplement or food ingredient and the claimed effect. Generally, a favourable outcome on all those three criteria leads to a positive opinion on the claim [32]. When that is verified, EFSA NDA Panel further evaluates the following aspects of the claims [32]: (a) the effect on the function is significant in relation to the quantity of the food proposed to be consumed and if this quantity could reasonably be consumed within a balanced diet; (b) the suggested wording reflects the scientific evidence; (c) the suggested wording and the proposed conditions and restrictions of use comply with the specific conditions set out in Article 10 of the Regulation (EC) no 1924/2006.

\begin{tabular}{|c|c|c|c|}
\hline \multicolumn{4}{|c|}{ HEALTH CLAIMS } \\
\hline $\begin{array}{c}\text { Feneral Function } \\
\text { Claims } \\
\text { (Article 13.1) }\end{array}$ & $\begin{array}{c}\text { New Function } \\
\text { Claims } \\
\text { (Article 13.5) }\end{array}$ & $\begin{array}{c}\text { Clisease Risk } \\
\text { Reduction } \\
\text { (Article 14.1.a) }\end{array}$ & $\begin{array}{c}\text { Child Development or } \\
\text { Health } \\
\text { (Article 14.1.b) }\end{array}$ \\
$\begin{array}{c}\text { Based on Generaly } \\
\text { Accepted Scientific } \\
\text { Evidence including } \\
\text { Scientific Studies } \\
\text { In Humans }\end{array}$ & $\begin{array}{c}\text { Based on New } \\
\text { Scientific Evidence or } \\
\text { Protection of } \\
\text { Propriety Data } \\
\text { including } \\
\text { Scientific Studies } \\
\text { In Humans }\end{array}$ & $\begin{array}{c}\text { Based on Specific } \\
\text { Scientific Studies } \\
\text { In Humans }\end{array}$ & $\begin{array}{c}\text { Based on Specific } \\
\text { Scientific Studies } \\
\text { In Children }\end{array}$ \\
& $\begin{array}{c} \\
\end{array}$ & & \\
\hline
\end{tabular}

Fig. 1. Schematic overview of health claim types in the Regulation (CE) № 1924/2006 
All NDA Panel scientific assessment are published in the EFSA Journal as EFSA scientific opinions.

In practice, the possible conclusions of each EFSA claim assessment outcome are the following [32]: (I) a cause and effect relationship has not been established between the consumption of the food/food supplement or food ingredient and the claimed effect (e.g. where the scientific evidence is limited and is not supported by the so-called 'generally accepted scientific evidence'); (II) the evidence provided is insufficient to establish a cause and effect relationship between the consumption of the food/food supplement or food ingredient and the claimed effect (e.g. where the scientific evidence is limited and is not supported by the so-called 'generally accepted scientific evidence'); (III) a cause and effect relationship has been established between the consumption of the food/food supplement or food ingredient and the claimed effect. These scientific opinions are used by the Commission to decide on the approval and market access or on the rejection of the claims. Finally, the outcome of the Commission's decision is published as a Commission Regulation and all claims are included in an online database of permitted and non-authorised health claims, the EU Register of Nutrition and Health Claims made on Foods, hereinafter referred to as 'the EU Register', including FS (http://ec.europa.eu/nuhclaims/) [18].

\subsubsection{Health claims for articular joint health}

By April 2, 2015 Commission had reviewed and decided on 2282 health claims: $11 \%$ were authorized while the great majority was nonauthorized (89\%). General claims (92\%) were the predominant types of claims listed in the EU Register; new function claims and claims

Table 2. Implementation of EU regulation № 1924/2006: overview of key requirements for health claims on food supplements

\begin{tabular}{|c|c|c|c|}
\hline \multirow{2}{*}{ Legal Requirement ${ }^{\text {(reterence in the act) }}$} & \multicolumn{3}{|c|}{ Health Claim Type } \\
\hline & $\begin{array}{l}\text { NF } \\
\text { (Article 13.5) }\end{array}$ & $\begin{array}{l}\text { DRR } \\
\text { (Article 14.1.a) }\end{array}$ & $\begin{array}{l}\text { CDH } \\
\text { (Article 14.1.b) }\end{array}$ \\
\hline \multicolumn{4}{|l|}{ REG 1924/2006* } \\
\hline \multicolumn{4}{|l|}{ The health claim shall comply /be ... } \\
\hline \multicolumn{4}{|l|}{$\begin{array}{l}\text { I. With the General Conditions, namely: } \\
\ldots \text { truthful, clear, reliable }{ }^{\text {(Article3) }} \text {, useful }{ }^{\left({ }^{(A r t c l e ~ b .2) ~}\right.} \text { and their } \\
\text { use justified }{ }^{\text {(Article 6.2) }} \text { by all relevant elements and data } \\
\text { (Article 6.3); }\end{array}$} \\
\hline $\begin{array}{l}\text { In the Food Supplements, the nutrient(s) or substance(s) } \\
\text { for which the claim is made is in a quantity that will } \\
\text { produce the physiological effect claimed and is in a form } \\
\text { that is available to the body }{ }^{\text {(Article 5.1); }} \\
\text { II. With the Specific Conditions, namely: }\end{array}$ & $\sqrt{ }$ & $\sqrt{ }$ & $\sqrt{ }$ \\
\hline 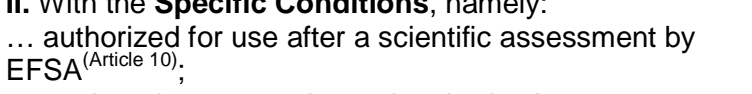 & $\sqrt{ }$ & $\sqrt{ }$ & $\sqrt{ }$ \\
\hline $\begin{array}{l}\text {... undergoing an accelerated authorisation } \\
\text { procedure }^{(\text {Article 18); }}\end{array}$ & $\sqrt{ }$ & $\mathrm{X}$ & $\mathrm{X}$ \\
\hline${ }_{i 5-17,19)}$ undergoing an complex authorisation procedure ${ }^{(\text {Articles }}$ & $\mathrm{X}$ & $\sqrt{ }$ & $\sqrt{ }$ \\
\hline \multicolumn{4}{|l|}{$\begin{array}{l}\text { REG } 353 / 2008^{*} \\
\text { III. An applicant for a health claim authorisation shall } \\
\text { comply /be ... }\end{array}$} \\
\hline $\begin{array}{l}\text {... prepared and presented complying with the technical } \\
\text { rules established in the Annex }{ }^{(\text {Article 10; }}\end{array}$ & $\sqrt{ }$ & $\sqrt{ }$ & $\sqrt{ }$ \\
\hline $\begin{array}{l}\ldots \text { to newly generally scientific evidence }{ }^{(\text {Artcle } 1 . b, 4)} \\
\ldots \text { to protection of proprietary data when requested } \\
\text { (Article }\end{array}$ & $\sqrt{ }$ & $\mathrm{x}$ & $\mathrm{X}$ \\
\hline i..b, 4); & $\sqrt{ }$ & $\sqrt{ }$ & $\sqrt{ }$ \\
\hline $\begin{array}{l}\text {...requiring a complete dossier containing all relevant } \\
\text { scientific data }\end{array}$ & $\sqrt{ }$ & $\sqrt{ }$ & $\sqrt{ }$ \\
\hline 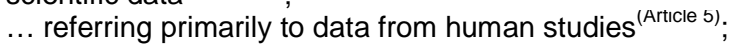 & $\sqrt{ }$ & $\sqrt{ }$ & $\sqrt{ }$ \\
\hline $\begin{array}{l}\text {...referring primarily to data from scientific studies in } \\
\text { children }^{(\text {Article } 5)} \text {; }\end{array}$ & $\mathrm{X}$ & $\mathrm{x}$ & $\sqrt{ }$ \\
\hline
\end{tabular}


regarding disease risk reduction claims and child development or health were in great minority ( $4 \%, 2 \%$ and $2 \%$, respectively). It is important to note that scientific assessment of Article 13.1 claims did not require the submission of dossiers by applicants [17]. EFSA received from the Member States via European Commission a list of those claims 'accompanied by the conditions applying to them and by references to the relevant scientific justification' [17].
Among the 2282 health claims 77 and $66(3.1 \%$ and $2.9 \%$ ) contained, respectively the descriptors 'joint' and 'maintenance of joint' and 44 of these claims relates to a health relationship on 'maintenance of joint' (Table 4). The FS constituents that were the subject of the 77 health claims on joints health, grouped into the four categories proposed by the European Advisory Services [25] are presented on Table 5.

Table 3. Overview of EFSA's relevant guidance for FS health claims on joints

\section{Document \\ EFSA NDA Panel Scientific \\ Opinion Scientific and \\ technical guidance for the \\ preparation and presentation \\ of an application for \\ authorisation of a health claim (revision 1). \\ EFSA NDA Panel Scientific Opinion General guidance for stakeholders on the evaluation of Article 13.1, 13.5 and 14 health claims. \\ EFSA NDA Panel Scientific Opinion Guidance on the scientific requirements for health claims related to bone, joints, skin, and oral health}

ESCO Report. Advice on the EFSA guidance document for the safety assessment of botanicals and botanical preparations intended for use as food supplements, based on real case studies

Topic
General Guidance on
how to submit claims
General Guidance on
how to submit claims
Specific Guidance on
the scientific
requirements for health
claims related to joints
Safety Assessment of
botanicals and
botanicals preparations
intended for use as
ingredients in food and
food supplements

Relevance

Covers the general require-

ments for the preparation and presentation of an application for authorisation of a health claim.

Covers the principles applied by the EFSA NDA Panel in the evaluation of health claims.

Sets guidelines on the scientific requirements for health claims related to joints health, representing the views of the NDA Panel based on the experience gained to March 2011 with the evaluation of joints health claims.

This guidance document EFSA Journal focuses on the safety 2009; 7(9):280 assessment of botanicals and botanicals preparations intended for use as ingredients in food and food supplements, including the safety assessment of botanicals reported to contain toxic, addictive or psychotropic substances and of botanicals reported to have also a medicinal use.

EFSA - European Food Safety Authority; ESCO - EFSA Scientific Cooperation; EFSA NDA Panel - EFSA Scientific Panel on Dietetic Products, Nutrition and Allergies; FS - Food Supplements.

Table 4. Health Claims on Joints included in the EU Register on Nutrition and Health Claims*

\begin{tabular}{|c|c|c|c|c|c|c|}
\hline \multirow[b]{2}{*}{ Search term } & \multicolumn{2}{|c|}{$\begin{array}{l}\text { General function claims } \\
\text { (Article 13.1) (n-) }\end{array}$} & \multicolumn{2}{|c|}{$\begin{array}{l}\text { "New" function claims } \\
\text { (Article 13.5) (n) }\end{array}$} & \multicolumn{2}{|c|}{$\begin{array}{l}\text { Disease risk reduction claims } \\
\text { (Article 14.1.a) (n) }\end{array}$} \\
\hline & Permitted & Non-authorised & Permitted & Non-authorised & Permitted & Non-authorised \\
\hline Joints & 0 & 70 & 0 & 7 & 0 & 0 \\
\hline $\begin{array}{l}\text { Maintenance } \\
\text { of Joint }\end{array}$ & 0 & 64 & 0 & 2 & 0 & 0 \\
\hline $\begin{array}{l}\text { Maintenance } \\
\text { of Joint** }\end{array}$ & 0 & 43 & 0 & 1 & 0 & 0 \\
\hline
\end{tabular}


Table 5. FS and FS ingredients target regarding Health Claims on Joints included in the EU Register on Nutrition and Health Claims*

\begin{tabular}{|c|c|c|}
\hline & & FS or FS Constituent \\
\hline Nutrient/Other substances & $\mathrm{HC}\left(\mathrm{n}^{\circ}\right)$ & \\
\hline Minerals & 10 & Boron, Zinc, Selenium, Silica \\
\hline Botanicals & 7 & $\begin{array}{l}\text { Astaxanthin from Haematococcus pluvialis, Advocado-soy } \\
\text { extract, Citrus flavonoid extract, Cherries (Prunnus Cerasus L.) } \\
\text { extract, Pineapple (Ananas comosus L.) stem }\end{array}$ \\
\hline Essential fatty acids & 19 & $\begin{array}{l}\text { EPA/DHA, Evening Primerose oil (Oenothe Biennis (L.)), } \\
\text { Borage oil (Borage officinalis L.), Fish oil, Gamma - linolenic } \\
\text { acid, Krill oil extract }\end{array}$ \\
\hline $\begin{array}{l}\text { Miscellaneous bioactive } \\
\text { substances }\end{array}$ & 41 & $\begin{array}{l}\text { Soy Isoflavones, Shark cartilage extract, Chondroitin sulphate, } \\
\text { Glucosamine, Hyaluronic acid, Mucopolysaccharides, SAMe, } \\
\text { Collagen hydrolysate, Monométhylsilanetriol, } \\
\text { Methylsulfonylmethan (MSM), Green Lipped Mussel (Mussel } \\
\text { perna canaliculus), Keratine powder extract, jelly royal, Sulphur }\end{array}$ \\
\hline Total & 77 & \\
\hline
\end{tabular}

The nutrient or substance target that were the subject of all 77 health claims on joints health included minerals (13\%) and above all other substances (87\%) (Table 5). Among other substances that could be used in FS there were primarily miscellaneous bioactive substances $(53 \%)$, essential fatty acids (e.g. the omega-3 fatty acids, eicosapentaenoic acid (EPA) and docosahexaenoic acid (DHA) (25\%) and some botanicals extracts (9\%). The miscellaneous bioactive substance category reunited various substances, namely glucosamine, chondroitin sulphate, hyaluronic acid and soy isoflavones, some extracts of animal origin (e.g. shark cartilage extract and keratine powder extract) and even an honey product (jelly royal), not to constitute a new category with this ingredient.

As noted above, all these function claims were considered non-authorised. They were mainly general functional claims (91\%). In the EU Register, the reasons shown for the nonauthorization of the health claims related to joints are the following: 'Non-compliance with the Regulation because on the basis of the scientific evidence assessed, this claimed effect for this food has not been substantiated' (69 Article 13.1 claims and 6 Article 13.5 applications) 'Noncompliance with the Regulation because on the basis of the scientific evidence assessed, this claimed effect for this food is not a beneficial physiological effect as required by the Regulation.' (1 Article 13.1 claim); 'this claimed effect attributes to this food the property of preventing, treating or curing a human disease, or refers to such properties which is prohibited for foods. Non-compliance with the Regulation because on the basis of the scientific evidence assessed' (1 Article 13.5 application). Briefly, these statements include one medical claim, one claimed effect not considered a beneficial physiological effect, while for the great majority $(97 \%)$ the claimed effect has not been scientifically substantiated. A deeper understanding of the reasons for these rejections requires an analysis of the scientific opinions from EFSA.

In the EFSA Scientific Opinions related to maintenance of joint health, the NDA Panel concluded that a cause and effect relationship has not established between the consumption of the nutrients or substances and the maintenance of normal joint. Globally, the main statements that EFSA Panel considered for the non-approval of the health claims on joints are the following: the human studies conducted in diseased population (namely RA [33], osteoarthritis [34] and juvenile arthritis [35]; the results from studies in diseased population cannot be extrapolated to the maintenance of a joint's function in the general population; studies with outcomes unrelated to the claimed effects [36]). According to the NDA Panel, a diseased population is not representative of the general population with regard to the functional conditions of the joints $[34,35]$. Some of the intervention studies were of small sample sizes and did not include healthy controls [37]. A number of references were provided on studies performed in animals and in vitro [34]. On this type of evidence, namely in a scientific opinion related to citrus bioflavonoids and maintenance of joint [34] the NDA Panel considered that the evidence provided in animal 
studies and/or in vitro studies was not sufficient to predict the occurrence of an effect of the food/food constituent and the maintenance of normal joints in vivo in humans. Some of the studies provided for joints health claims have been carried out with the target substance for which the claim was made mixed with others ingredients or with others substances [38]. The NDA Panel did not considered those studies as pertinent, i.e. studies from which conclusions can be drawn for the scientific substantiation of the claim [39]. Finally, in a randomized double-blind placebo controlled trial provided in the application referred above, the NDA Panel pointed out some negative aspects related to the statistical analysis (power calculation, missing data and multiple comparisons adjustment) [38]. As result, that evidence has been considered irrelevant for the scientific substantiation of the claim. On the other side, the NDA Panel stated clearly that claimed effects like 'joint health' [37,40], 'joint support' [41], 'joint mobility' [42], among others, relate to the maintenance of normal joints. In all cases, EFSA recognizes that maintenance of normal joints is beneficial to human health, assuming that the target population is the general (healthy) population. An overview of some of the 21 Scientific Opinions of the NDA Panel relating to the 77 submitted applications for health claims on maintenance of joint health is presented in Table 6 .

The health claim related to $\mathrm{Eff}_{\mathrm{EXT}}{ }^{\mathrm{TM}}$, a lipid standardized extract from the crustacean Euphausia superba (Antarctic Krill), and the claimed effect 'helps to support joint function by maintaining low levels of plasma C-reactive protein' was considered by the NDA Panel to be a medicinal claim [43] (Table 6.). This claim refers to a reduction of inflammation indicated by a lowered concentration of plasma C-reactive protein. According to NDA Panel, 'whether or not reduction of inflammatory markers is considered beneficial depends on the context in which a claim is made' [43]. Although the target population was adults presenting with sensitive joints, the randomized, double bind, placebo controlled study that supported the scientific assessment of the claim was carried out in patients with confirmed inflammatory diseases, namely osteoarthritis and rheumatoid arthritis [44]. In that context, the NDA panel concluded that the reduction of inflammation in the context of that diseases is a therapeutic target for the treatment of the disease and does not comply with the criteria laid down in Regulation (EC) No 1924/2006 [43]. Finally, the health claim regarding a bee product, Royal jelly, and an antiinflammatory effect (helps to reduce inflammation in joints and muscles') based on changes in markers of inflammation (various interleukins) was evaluated by the NDA Panel [45]. As no evidence has been provided in which context the claimed effect could be considered as a beneficial physiological effect, the Panel concluded that for this case, the reduction of inflammation was not considered a beneficial physiological effect as required by the Regulation [45].

Although all health claims applications on articular joints were refused authorisation, one general function claim on vitamin $C$ related to cartilage formation was authorised - 'Vitamin C contributes to normal collagen formation for the normal function of cartilage [46]. As cartilage formation is related to joints this health claim and their EFSA positive opinion will also be considered in the following discussion. Bioactive phenolic compounds from red raspberry, above all ellagitannins and anthocyanins, are substances with potential value regarding the joints health $[13,47]$. Even though scientific evidence on a possible beneficial physiological effect of those phytochemicals on joints is still very insufficient, the discussion will also consider a favourable assessment of EFSA on olive oil polyphenols.

\subsection{Discussion}

In Europe, the prevalence of joint disease, including RA, is high but there is a considerable proportion of subjects in the general population who complain of joint pain or joint discomfort, even without evidence of disease $[9,48]$. While the treatment of joint diseases must be addressed by pharmacological treatments, among others, such complaints could improve with the intake of FS which claim an effect on joints health. According to Bruyère et al. [49], a substantial proportion of subjects with joint discomfort or at risk of joint disorder use FS claiming a beneficial effect on joint and cartilage health. The analysed health claims on joints are related to ingredients (a nutrient or other(s) substance(s)) that can be used in FS. 
Table 6. Overview of some EFSA NDA panel scientific opinions regarding heath claims on joints

\begin{tabular}{|c|c|c|c|c|}
\hline $\begin{array}{l}\text { EFSA } \\
\text { Opinion } \\
\text { Reference }\end{array}$ & $\begin{array}{l}\text { Nutrient or } \\
\text { Substance }\end{array}$ & Claim $^{\text {(ID Entry) }}$ & Status & $\begin{array}{l}\text { Assessment } \\
\text { Statement }\end{array}$ \\
\hline $\begin{array}{l}\text { EFSA Journal } \\
2009: 7(9): \\
1229\end{array}$ & Zinc & $\begin{array}{l}\text { Zinc promotes joint health Zinc helps } \\
\text { support the function of the joints }{ }^{(\mathrm{ID} 305)}\end{array}$ & NA & $\begin{array}{l}\text { The claimed effect has } \\
\text { not been substantiated. } \\
\text { Criterion III was not } \\
\text { observed. }\end{array}$ \\
\hline $\begin{array}{l}\text { EFSA Journal } \\
2009: 7(9): \\
1261\end{array}$ & $\begin{array}{l}\text { Boron } \\
\text { as Boric Acid }\end{array}$ & $\begin{array}{l}\text { Boron helps build and maintain healthy } \\
\text { joints. Boron helps maintain the } \\
\text { flexibility and mobility of the joints (ID } \\
219) ; \text { Boron may help maintain joint and } \\
\text { bone health. Boron involved in joint } \\
\text { health. Boron required for joint health } \\
\text { (ID 220) }\end{array}$ & NA & $\begin{array}{l}\text { The claimed effect has } \\
\text { not been substantiated. } \\
\text { Criterion III was not } \\
\text { observed. }\end{array}$ \\
\hline $\begin{array}{l}\text { EFSA Journal } \\
2009: 7(9): \\
1266\end{array}$ & Hyaluronic Acid & 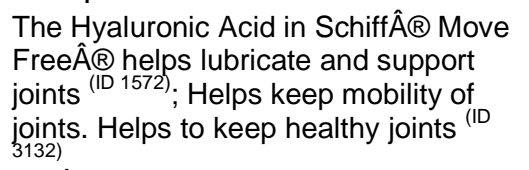 & NA & $\begin{array}{l}\text { The claimed effect has } \\
\text { not been substantiated. } \\
\text { Criterion III was not } \\
\text { observed. }\end{array}$ \\
\hline $\begin{array}{l}\text { EFSA Journal } \\
2009: 7(9): \\
1477\end{array}$ & $\begin{array}{l}\text { Gamma-Linolenic } \\
\text { Acid provided by } \\
\text { evening primrose } \\
\text { oil and/or borage } \\
\text { (starflower) oil }\end{array}$ & $\begin{array}{l}\text { Helps maintain healthy supple and } \\
\text { flexible, mobile joints }{ }^{\text {(ID } 494)} \text {; Helps } \\
\text { maintain joint health/ supports joint } \\
\text { flexibility/supports mobility (ID 637); } \\
\text { Helps maintain joint health/supports } \\
\text { joint flexibility/supports mobility (ID 1744). }\end{array}$ & NA & $\begin{array}{l}\text { The claimed effect has } \\
\text { not been substantiated. } \\
\text { Criterion III was not } \\
\text { observed. }\end{array}$ \\
\hline $\begin{array}{l}\text { EFSA Journal } \\
2010: 8(2): \\
1477\end{array}$ & $\begin{array}{l}\text { Gamma Linolenic } \\
\text { Acid; Oenothera } \\
\text { biennis (Common } \\
\text { Name : Evening } \\
\text { Primrose) }\end{array}$ & $\begin{array}{l}\text { Improves mobility and elasticity of } \\
\text { joints. Activates absorption of calcium } \\
\text { in intestinal tract thus increasing bone } \\
\text { tissue density }{ }^{(\mathrm{ID}} \text { 1774); Helps maintain } \\
\text { supple and flexible joints }\end{array}$ & NA & $\begin{array}{l}\text { The claimed effect has } \\
\text { not been substantiated. } \\
\text { Criterion III was not } \\
\text { observed. }\end{array}$ \\
\hline $\begin{array}{l}\text { EFSA Journal } \\
2009: 7(9): \\
1493\end{array}$ & $\begin{array}{l}\text { Mucopolysacchar } \\
\text { ides; Isoflavones }\end{array}$ & $\begin{array}{l}\text { Mucopolysaccharides help maintaining } \\
\text { healthy joints }{ }^{(I D ~ 3624)} \text {; helps to maintain } \\
\text { mobility of joint during and after } \\
\text { climacterium }^{(\text {ID } 3144)} \text {; }\end{array}$ & NA & $\begin{array}{l}\text { The claimed effect has } \\
\text { not been substantiated. } \\
\text { Criterion III was not } \\
\text { observed. }\end{array}$ \\
\hline $\begin{array}{l}\text { EFSA Journal } \\
2010: 8(2): \\
1477\end{array}$ & $\begin{array}{l}\text { Gamma } \\
\text { Linolenic Acid }\end{array}$ & $\begin{array}{l}\text { Improves mobility and elasticity of } \\
\text { joints. Activates absorption of calcium } \\
\text { in intestinal tract thus increasing bone } \\
\text { tissue density }{ }^{(I D ~ 1744)}\end{array}$ & NA & $\begin{array}{l}\text { The claimed effect has } \\
\text { not been substantiated. } \\
\text { Criterion III was not } \\
\text { observed. }\end{array}$ \\
\hline $\begin{array}{l}\text { EFSA Journal } \\
2010 ; 8(2): \\
1493\end{array}$ & $\begin{array}{l}\text { Citrus } \\
\text { bioflavonoids }\end{array}$ & $\begin{array}{l}\text { Citrus bioflavonoids may help to keep } \\
\text { joints healthy. }{ }^{(\text {1D } 1799) ;}\end{array}$ & NA & $\begin{array}{l}\text { The claimed effect has } \\
\text { not been substantiated. } \\
\text { Criterion III was not } \\
\text { observed. }\end{array}$ \\
\hline $\begin{array}{l}\text { EFSA } \\
\text { Q-2012-00386 }\end{array}$ & $\mathrm{Eff}_{\mathrm{EXT}} \mathrm{TM}^{*}$ & $\begin{array}{l}\mathrm{Eff}_{\mathrm{EXT}}{ }^{\mathrm{TM}} \text { may help to support joint } \\
\text { function by maintaining low levels of } \\
\text { plasma C-reactive protein; }\end{array}$ & NA & $\begin{array}{l}\text { The claimed effect } \\
\text { attributed to this food is } \\
\text { the property of } \\
\text { preventing, treating or } \\
\text { curing a human } \\
\text { disease, or refers to } \\
\text { such properties that are } \\
\text { prohibited for foods. } \\
\text { Criterion III was not } \\
\text { observed. }\end{array}$ \\
\hline $\begin{array}{l}\text { EFSA Journal } \\
2010 ; 8(10): \\
1799\end{array}$ & Gelée Royale** & $\begin{array}{l}\text { Gelée Royale may help to reduce } \\
\text { inflammation in joints and muscles. } \\
\text { 1327); }\end{array}$ & NA & $\begin{array}{l}\text { The claimed effecf for } \\
\text { this food is not a } \\
\text { beneficial physiological } \\
\text { effect as required by } \\
\text { the Regulation. } \\
\text { Criterion II was not } \\
\text { observed. }\end{array}$ \\
\hline
\end{tabular}


All 77 functional health claims on joints health submitted under the Regulation (EC) $\mathrm{n}^{\circ}$ 1924/2006 on nutrition and health claims on food were refused authorisation. Indeed, 76 of the proposed health claims on joints were considered not supported by a sufficient body of scientific evidence able to substantiate the relationship between the consumption of the foodstuff and the claimed effect. The EFSA NDA Panel stated that results from studies performed in diseased population subgroups cannot be used for the scientific substantiation of health claims on joints function in the general population [39]. It is important to note that EFSA's specific guidance on the scientific requirements for health claims related to joints became available in 2011 (the draft version) for public consultation. The final version of that guidance was published in 2012. This EFSA document aims to assist applicants in preparing and submitting their applications for the authorization of health claims on joints. However, the vast majority of the applicants of the health claim applications on joints analysed (70 general functional health claims), if not all applicants (70 Article 13.1 claims and 7 Article 13.5 claims) did not benefited from such guidance. On the contrary, the NDA Panel set out its guidance in the area of joints health from the evaluation of the vast majority of those applications [39].

On the subject of applications about food / foodstuff / substances or nutrients claiming treatment or prevention of joint diseases, Article 7.3 of Regulation (EU) no 1169/2011 on the provision of food information to consumers [8] clearly states that 'Subject to derogations provided for by Union law applicable to natural mineral waters and foods for particular nutritional uses, food information shall not attribute to any food the property of preventing, treating or curing a human disease, nor refer to such properties'. The law prohibiting 'the use of information that would mislead the purchaser or attribute medicinal proprieties to food' [17] was also explicit in the general labelling EU provisions, the Directive 2000/13/EC on food labelling, repealed in 2011 by the act mentioned above. This legal requirement is also part of the legislation on $\mathrm{FS}$, in particular Article 6.2 of the FSD.

Comparing all statements found in the EFSA reports evaluating the 77 health claim relating to joints health it is important to emphasize that in all cases, the target nutrients/substances are sufficiently characterized. Success in meeting the first criterion used by EFSA in the evaluation of health claims can be attributed to the ingredients found in these applications. In most cases (87\%), those ingredients are 'other substances'. Generally, the constituents claiming the physiological beneficial effect on joints function are well defined and characterized and can be measured in foodstuff by established methods. It is important to emphasize that in those cases, as with drugs, only one or a limited number of active components were measured. These results raise the following question: Would more complex matrices such as food in general or even the red raspberry extract rich in phenolic compounds [13], mentioned above be positively evaluated by EFSA with regard to this criterion or, as olive oil polyphenols (e.g. hydroxytyrosol and oleuropein complex) that have been positively assessed by EFSA [50] should the focus be placed on only some of its bioactive phenolic compounds? It is important to clarify that the olive oil constituents subject of the health claim regarding olive oil are olive oil polyphenols standardized extracts, namely a hydroxytyrosol or oleuropein complex and an Olea europaea L. extract standardized to $4-23 \%$ oleuropein. Those phenolic acids can be found in the olive fruit, olive mill waste waters or olive oil, Olea europaea L. extract and leaf [50].

The preparation of a stand-alone dossier containing the information and the scientific data submitted for authorisation of a health claim related to the consumption of a FS or its constituents, including other substance or substances, requires compliance with certain legal requirements particularly with regard to food safety issues. The legal framework regarding these products has some limitations that are worth discussing.

At the European level, the FSD [14] harmonises partially the legal framework for the manufacture and marketing of products containing vitamins and minerals, laying down a European-wide positive list of vitamins and minerals that can be used in FS and their specific forms. The key provisions of the FSD include also specific labelling provisions. Decreto-lei no 136/2003 of July 28 [15], implements that legislation in Portugal. FS may be, according to the explicit definition found in these acts, concentrated sources of other substances with a nutritional or physiological effect taken alone or in combination, marketed in dose form. However, 'other substances' are not defined or included in those acts although it is generally understood that these substances could include, but not limit to, amino acids, enzymes, pre- and probiotics, essential fatty acids, fibers and various 
botanicals and botanical extracts like the Rubus idaeus L. extract referred previously. The term 'nutritional and physiological effect' is also not defined in Directive 2002/46/EC or in Decreto-lei no 136/2003 of July 28 and neither does it clarify the botanicals species and varieties that can be used in the manufacture of FS. (EU) no 1924/2006 defines 'other substances' as substances other than vitamins or minerals that have a nutritional or physiological effect however, the term 'nutritional and physiological effect' is not clarified [17]. It is interesting to highlight that the Croatian regulation on substances that may be added to foods and use in food and substances whose use in foods is prohibited or restricted, considers other substances as amino acids, essential fatty acids, fiber, plant organs, plant extracts, herbal products, microorganisms, edible fungi, algae, bee products and other substances with nutritious or physiological effect [51]. A recently subject to public consultation EFSA NDA Panel draft general guidance for stakeholders on the evaluation of Article 13.1, 13.5 and 14 health claims published in March 2011 defines other substances as 'any food/ constituent which is not an essential nutrient' [52]. This document establishes also that the general applied by the NDA Panel for the assessment of health claims on other substances differ from those applied for the assessment of claims functions of essential nutrients. The differences refer to the requirements for the definition of the claimed effect, for the scientific substantiation of the claim, and for establishing conditions of use [52]. Once it is adopted, this NDA Panel document will supersede the general guidance for stakeholders on the evaluation of Article 13.1, 13.5 and 14 health claims and the pre-submission guidance on administrative and procedural questions for applicants intending to submit applications for authorisation of health claims made on foods [52].

Permitted botanicals used, as target substances for the purpose of health claims, must assure their safety. In this regard it is important to note that the European Commission put those Article 13.1 claims on hold [52]. Also, FS not present at a significant degree on the EU market before May 15, 1997 should be previously authorized as new ingredients, as e.g. Krill oil, the functional ingredient of health claims related to the improvement of joint flexibility, the maintenance of joint comfort and the maintenance of joint mobility [53,54].
Considering the aforementioned, in the case of other substances with a physiological effect, namely botanicals, the EU legislation ensures limited harmonization. As a consequence, there are major differences among the rules for marketing FS in the different EU member States (Table 7). Therefore, decisions regarding the safety and effectiveness of FS with those ingredients depend mainly on national legislation and manufacturer's practices [11]. Portuguese legislation, establish rules regarding vitamins and minerals that can be used in the manufacture of FS but nothing is explicit regarding other substances. A provision intended to facilitate efficient monitoring of FS (Article 9 of Decreto-Lei no 136/2003), requiring the manufacturer or the person placing the product on the market to notify the competent authority of that action by forwarding to the authority a copy of the label used for the product. This notification can assure some control over the other substances used in FS. Generally, in Portugal a various range of other substances are permitted for use in FS either under national law or internal guidelines Regulation (Table 7). On the contrary, e.g. in France, those ingredients are not currently permitted, although its use in FS may be permitted following a pre-marketing authorisation.

The main categories of other substances within the EU market are amino acids, enzymes, preand probiotics, essential fatty acids, botanicals and botanical extracts, and miscellaneous bioactive substances [24]. Specific rules for the use of other substances are subject to national law and/or internal guidelines, with negative and positive lists and considering specific conditions of use. A significant proportion of the EU market of the miscellaneous bioactive substances and botanicals (e.g. glucosamine, gingko) is composed of products registered as medicines (e.g. glucosamine is considered by the German authorities to be a medicine whereas in others Members States, namely UK, is available as FS) [22]. These borderline cases regarding botanicals and other bioactive substances, namely herbal extracts, are used in FS and for manufacturing proprietary medicinal products, in particular traditional herbal medicinal products [23]. Medicinal products are regulated under the Directive 2001/83/CE, the Directive 1999/83 for medicinal products with well-established use, and under the Directive 2004/24/CE on Traditional Herbal Medicine Products adopted in 2004 [55,56,57]. In some UE Member States some botanicals products and miscellaneous 
bioactive substances are regulated under the Traditional Herbal Medicine Products Directive (THMPD), through a simplified traditional use registration that recognizes, under certain strict conditions, the importance of the evidence of 'traditional use' regarding the safety and the efficacy of those products (30 years of traditional use in Europe or 15 years in Europe and 15 years in the world; a prove of efficacy is not required) [57]. This approach and the one established by Regulation (CE) № 1924/2006 regarding claims on food and foodstuff are, as we shall see below, contradictory.

The second criterion adopted by EFSA for the scientific assessment of health claims on foodstuff - the claimed effect is defined and is beneficial - has been verified successfully in the vast majority of the 77claims. It is important to note that for function claims, the 'maintenance of joint function' claimed by $86 \%$ of the applications for joints analysed, viewed by the NDA Panel as a possible 'reduced loss' of joint function [36], is considered a beneficial physiological effect. For these claims, a beneficial effect can also relate to the improvement of joint function. Considering the analysis in the broader perspective of the 2822 claims evaluated up to April 2, we find that in many cases the NDA Panel did not consider the effect claimed in applications as beneficial to human health, such as in claims related to antioxidants $[4,58]$ and probiotics $[59,60]$.

The implementation of Regulation (EC) No 1924/2006, particularly the scientific assessment of the health claims applications, has been controversial. EFSA assesses the substantiation of health claims based on scientific evidence of the highest possible standard and the European Commission and Member States decide on their authorisation. Considering the legal provisions established in the Regulation (EC) No 1924/2006 and relative acts, the evidence of 'traditional use' is insufficient to prove the substantiation of claims on botanicals and others miscellaneous bioactive substances. In this context it was generated in the EU market a controversial situation regarding medicinal products and food, usually FS. Some botanical or miscellaneous bioactive substances are used in both FS and medicines (e.g. glucosamine) [24]. As observed in this study, considering the rules of the Regulation (EC) No 1924/2006 it was expected that, in most, if not all, health claims on botanicals would be rejected. Regarding this situation the Commission, in agreement with the Member States, decided to reflect on this issue while the health claims on botanicals are put 'on hold' Regarding the resolution of this regulatory hiatus on botanicals, the two options put forward by the Commission are the following: (1) uphold the status quo, justifying the different treatment of botanicals between food and medicines; (2) consider that difference in treatment would not be justified. In this last position, botanicals would be considered a particular case in the food area, with eventually news rules recognising the importance of evidence of 'traditional use' [11,61]. Three Member States with great experience and tradition in FS containing botanicals (Italy, France and Belgium), supported by scientific expertises in this area joined forces in the BELFRIT project [62]. This project enhances the importance of the quality and safety aspects regarding botanicals used in FS and food in general. This debate on this issue is not completed yet.

Several stakeholders, including the scientific community, have been questioning EFSA's decisions and presenting their vision and/or suggestions on general aspects and regarding specific functions. The Group for the Respect of Ethics and Excellence in Science, GRES, published in 2012 a commentary on health claims assessment in the field of joint and cartilage [49]. In 2011, EFSA and its NDA Panel have carried out a written public consultation with stakeholders, on the draft document of the guidance on the scientific requirements for health claims related, among others, to joints health. A summary of the comments received by all interested parties (e.g. academia and research institutes, industry organizations and applicants for health claims) and of how the comments were addressed by the NDA Panel is part of EFSA's technical report published in 2012 [63]. According to this report, the NDA Panel's final version of the guidance document took into account the questions/comments received in that public consultation.

Possible outcomes for Article 13.5 claims related to joint function could include a foodstuff that could decrease joint discomfort, e.g. stiffness and pain, improve joint mobility or changes in joint structure leading to maintenance of joint function [35]. In this regard, the NDA Panel scientific requirements for health claims related to joint function are aligned (both possible outcomes and outcomes measures) with the viewpoint of the GREES Panel [49]. The GREES Panel considers three potentially Article 13.5 health claims on joints health: decrease in joint 
discomfort, improvement in joint mobility and maintenance of structural joint integrity. According to the NDA Panel [39], decrease in joint discomfort and improvements in joint mobility are possible outcomes for the maintenance (i.e. reduced loss) of joint function; changes in joint structure, namely in joint space width, leading to the maintenance of joint function(s), can also be considered beneficial physiological effects. Structural changes in joint tissues, or changes in biochemical markers, namely of joint inflammation, proposed as mechanisms by which the FS/food constituent may exert the claimed effect on joint function, may also be considered a beneficial physiological effect, based on a case-by-case approach [39].

The EU Register does not include Article 14.1 health claims for articular joints. For disease risk reduction claims the NDA Panel assumes that 'beneficial refers to whether the claimed effect relates to the reduction or beneficial alteration of a risk factor for the development (onset) of a human disease' (not the reduction of the risk of disease) [31]. From the NDA Panel perspective, an increased rate of joint cartilage degeneration can be considered a risk factor for the onset of osteoarthritis/degenerative arthritis [39]. Studies measuring net cartilage loss could be used for the scientific substantiation of diseased risk reduction claims referring to osteoarthritis [39]. On the contrary, the NDA Panel does not consider changes in biomarkers of cartilage degeneration or of collagen turnover as risk factors for disease risk reduction claims relating to osteoarthritis [39].

Scientific substantiation is the main aspect (and the greatest challenge) to take into account in health claims related to joint function. Human studies conducted in diseased populations are the main NDA Panel's criterion for the nonapproval of the health claims on joints. According to EFSA [39]: 'normal cells and tissues are genetically (gene expression) and functionally different from osteoarthritic cells and tissues and therefore may respond differently to interventions with exogenous substances' and 'the mechanisms involved in the onset and/or progression of osteoarthritis are largely unknown, so that it cannot be established that an intervention which has an effect on the progression of the disease (in patients with osteoarthritis), would also have an effect on its onset (subjects without the disease)'. On this subject the NDA Panel considered the findings of a study by Jordan et al. [64] entitled 'Methodological issues in clinical trials for prevention or risk reduction in osteoarthritis', published in 2011. The NDA Panel viewpoint on the eligible study populations is clear [39]: the demonstration of the health claims on joints has to be established in human intervention studies performed in non-diseased (including high risk) population subgroups (e.g. Kell-Lawrence radiographic scores 0 or 1 , obesity, knee varus or valgus malalignment). The EFSA NDA Panel guidance document recommends that the applicants provide information on the selection and characterisation of the study population in relation to the claimed effect and a rationale for extrapolation of the results to the target population for which the claim is made.

Methodological issues in the design of clinical trials are (critical) specific challenges essential for obtaining reliable outcomes in human studies to provide a scientific basis for health claims related to joint function. Generally, EFSA scientific assessment of Article 13.1 claims included separate assessment of each relationship between the functional constituent/food and a claimed effect, and combining individual assessments, in order to obtain coherent opinions $[34,37,40]$. The NDA Panel evaluation of general function claims was carried out, in accordance with the general guidance document [31], with the available documents cited in references received from the Member States and from those provided by stakeholders, including data that are derived from the state-of-the-art peer-reviewed published literature, e.g. handbooks and monographs. For those Article 13.1 claims on joints there was no established consensus and the primary studies assessed were conducted in diseased populations.

As referred previously, one general function claim on vitamin $C$ related to cartilage formation was approved by EFSA. However is important to note that the NDA Panel decision relied on well established biochemical role of vitamin $C$ in collagen structure and on Vitamin C deficiency symptoms on impaired collagen synthesis. Nowadays, the claim 'Vitamin C contributes to normal collagen formation for the normal function of cartilage' [46] is currently used on foodstuff. In order to bear this claim food supplement should be at least a source of vitamin C (i.e. $12 \mathrm{mg} / 100 \mathrm{~g}$ or $100 \mathrm{~mL}$ ) as per Annex to Regulation (EC) no 1924/2006 and Annex III to Regulation (UE) no $1169 / 2011$. 
Table 7. Overview on different national approaches for the use of some substances, other than vitamins and minerals, in the Member States of the UE*

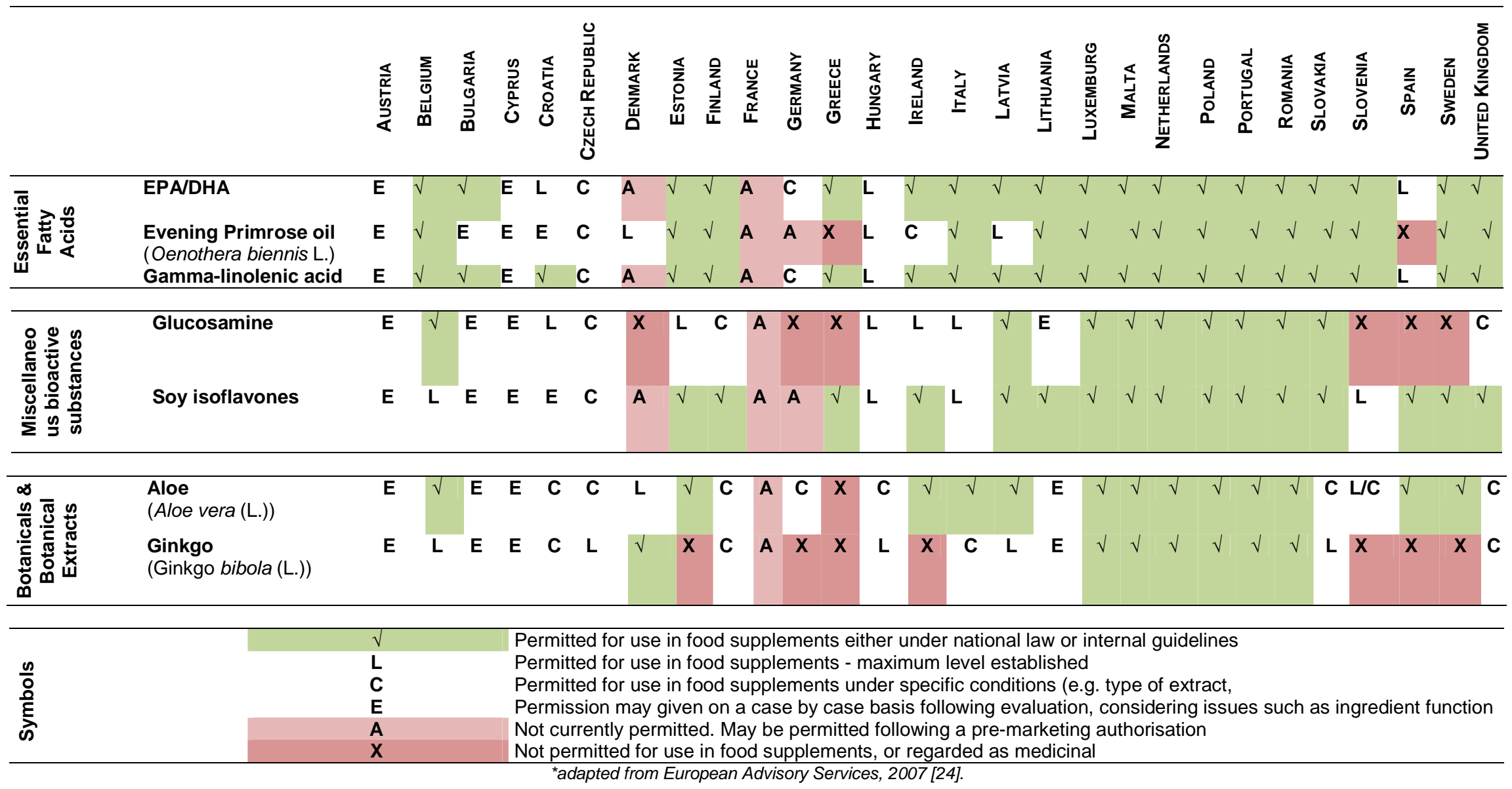


Well designed RCT studies are regarded as the most convincing proof for the scientific substantiation of health claims under Articles 13.5 and 14.1.a. According to experts, in addition to being costly and difficult experimentally, those studies are not always feasible or available for nutritional studies [31]. The recent NDA Panel (draft) General scientific guidance on health claims applications states that pertinent human studies are central for health claim substantiation and intervention human studies at the top of the hierarchy that informs decisions on substantiation [52]. The reason for this NDA Panel approach resides on the need to provide evidence from the impact of introducing or replacing a single food/constituent in the whole diet on the claimed effect. This document also clarifies that pertinent human studies are intervention and observational human studies from which scientific conclusions can be drawn for the substantiation of a claim. Intervention and observational human studies can also provide evidence for a dose response relationship and for consistency of the effect/or the association across studies. For these applications it is important to consider that the applicant has the responsibility to provide the totality of the data available, namely supportive evidence from reviews, in vitro and animal studies. However, efficacy studies in animals and non-efficacy studies in humans (e.g. evidence for a mechanism which a food could exert the claimed effect) may be part of the totality of the evidence only if pertinent human studies showing an effect of the food/constituent are available [52]. The human trials must be conducted in non-diseased population subgroups (including high risk), have high methodological and statistical quality (e.g. addressing confounding factors and having sufficient statistical power) [31,32]. In the recent NDA Panel (draft) guidance document it is recognized that: (I) 'the first-line therapy for patients with diet-related chronic diseases (e.g. obesity, type 2 diabetes, hypertension) is often dietary advice, and thus they could benefit the most from health claims made on foods'; (II) 'in some cases, the relationship between a food/constituent and a function can be best measured by using disease outcomes'; (III) 'with respect to the likelihood that the consumption of a food/constituent would effectively modify the risk of the disease, disease outcomes provide stronger evidence than risk factors for disease' and 'in some circumstances it may be easier to measure disease outcomes than risk factors for disease' and considering 'the likelihood that the consumption of a food / constituent would effectively modify the risk of the disease, disease outcomes provide stronger evidence than risk factors for disease' [52]. Consequently, among others, the Panel also considers that 'studies conducted in subjects with a disease may be used to substantiate function claims for the general population or subgroups thereof (without the disease) as long as the effect of the food/constituent on the body function which is named in the claim is expected to occur in subjects without the disease and a rationale is given for such expectations' [52]. On the study population, the GREES Panel suggested technical information to consider in future studies, along with EFSA's guidance recommendations $[39,49]$. The EFSA NDA Panel (draft) General scientific guidance on health claims applications is more aligned with the GREES Panel approach.

Not all human intervention studies are accepted by EFSA as evidence. In the positive opinion related to polyphenols on olive oil and protection of LDL particles from oxidative damage, the NDA Panel took into account a well conducted and powered study (a multicentre, randomized, cross-over, controlled human trial in 200 volunteers for 3 weeks) and two smaller-scale studies (a randomized, cross-over, controlled human trial in 36 volunteers for 3 weeks and a controlled, double-bind, cross-over, randomized, human trial in 30 and 12 healthy male volunteers for 3 weeks and 4 days, respectively); supported by one short-term (controlled, double-bind, cross-over, randomized, human trial in 12 healthy male volunteers for 4 days), and one acute (cross-over study design in 12 healthy male volunteers) and by supportive markers of LDL peroxidation [50]. Two other human trials (a randomized, single-blind, cross-over trial in 25 healthy male and female smokers for 3 weeks and a randomized, sequential cross-over, acute study in 21 hypercholesterolaemic volunteers) were not considered for the substantiation of the claimed effect [50]. In this scenario it is worth remembering that in time of financial crisis, conducting human studies able to meet those requirements is a huge financial effort, for many difficult to undertake. Finally, as for clinical trials on medicinal products for human use [65], the creation of harmonized scientifically robust criteria and guidance for the conduct of nutritional intervention studies in humans, more in line with the multiple effects of nutrition could have a huge impact on health claims on food in general $[31,66]$. In this regard, the recent EFSA NDA Panel (draft) General scientific guidance on 
health claims applications can represent an important shift regarding the evaluation of future health claims on joints [52].

\section{CONCLUSION}

FS in the EU market contain nutrients and other substances, namely amino acids, enzymes, preand probiotics, essential fatty acids, botanicals and botanical extracts, and miscellaneous bioactive substances. The key provisions of the FDS include a positive list of vitamins and minerals and of their specific forms and specific rules regarding labeling. Specific provisions for the use of other substances are subject to national law and/or internal guidelines, with negative and positive lists and considering specific conditions of use. Furthermore, a significant proportion of the EU market in some of the miscellaneous bioactive substances and botanicals are composed by products registered in different member States, both as medicines and as food. These borderline cases regarding botanicals and other bioactive substances raised up a great controversial in the EU, namely regarding the assessment of health claims on those products.

In the EU market FS cannot bear such health claims unless the claims have been authorised. But, since July 2007, with the entry into force of Regulation (EC) no 1924/2006 only health claims that are supported by a sufficient body of scientific evidence able to substantiate the relationship between the consumption of the foodstuff and the claimed effect are admitted. However, in general, the implementation of this Regulation has been very criticized, namely regarding the scientific assessment of health claims on other substances, namely botanicals and various miscellaneous bioactive substances.

EFSA assessment favours effects improving joints health of the consumer, as described in Regulation (EC) no 1924/2006. The 77 functional health claims on joints health included in the EU Register have not been authorised. According to EFSA assessments, applicants have provided very limited or no evidence, and no cause and effect have been positively assessed in each case. The main reason for EFSA non-approval is that the evidence submitted to EFSA for substantiation did not establish that data from diseased groups can be extrapolated to the general population that is the target for these claims. However, it is relevant to note that EFSA's criteria I (the target ingredient is defined and characterized), and II (the claimed effect is a beneficial physiological effect), have been positively assessed in 75 claims.

Some of the 77 health claims on joints analysed in this work were made on botanicals and miscellaneous bioactive substances. Depending on the intended use of the product, these same ingredients can also be used in medicines. Many of these medicinal products are regulated under the Traditional Herbal Medicine Products Directive, through a simplified traditional use registration that recognizes, under certain strict conditions, the importance of the evidence of 'traditional use', regarding both safety and efficacy of these products. On the contrary, under Regulation (CE) no 1924/2006, the evidence of 'traditional use' is not sufficient to prove the substantiation of claims on botanicals and others miscellaneous bioactive substances. Regarding the resolution of this regulatory hiatus on botanicals, some options are currently in discussion: (1) upholding the status quo, justifying the different treatment of botanicals between food and medicines; (2) accepting that difference in treatment would not be justified with different rules recognising the importance of evidence of 'traditional use'. The importance of the quality and safety aspects regarding botanicals used in FS and food in general has been pointed out by the BELFRIT project as crucial. In our point of view, this debate could provide new insights regarding the implementation of Regulation (EC) no 1924/2006.

It is important to learn from the experience of this scientific assessment by the EFSA in order to achieve in having FS with authorized health claims related to joint health and to ensure confidence in claims on FS, including FS containing botanicals ingredients. Thus, research strategy and tools should be oriented to meet the legal requirements in force and the EFSA scientific guidelines recommendations. However, criteria and more detailed guidance documents provided by EFSA with a collaborative involvement of stakeholders, including scientists from academia and research institutes, especially addressing methodological issues on human trials in general and related to the joints function, would benefit all future applications and scientific research in this field. Specific legal issues regarding other substances, namely botanical ingredients and botanical preparations, should also be taken into account in future FS health claims on articular joint. On legal subjects, it would be advisable for the European 
Commission and Member States to undertake efforts to improve the existing regulatory framework, namely with regard to FS.

\section{COMPETING INTERESTS}

Authors have declared that no competing interests exist.

\section{REFERENCES}

1. World Health Organization. Global status report on noncommunicable diseases 2014. WHO Press, Geneva, Switzerland. 2014;298. ISBN: 978924156485 4, Available:http://www.who.int/nmh/publicati ons/ncd-status-report-2014/en/

2. OECD. Health at a glance: Europe 2014. OECD Publishing. 2014;141. Paris, France. ISBN 978-92-64-22327-1 - 2014 Available:http://ec.europa.eu/health/reports /docs/health glance 2014 en.pdf

3. World Health Organization. Global Action Plan for the Prevention and Control of NCDs 2013-2020. WHO Press, Geneva, Switzerland. 2013;103. ISBN 978924 1506236.

Available:http://www.who.int/nmh/events/n cd action plan/en/

4. Verhagen H, Vos E, Franci S, Heinonen M, van Loveren $H$. Status of nutrition and health claims in Europe. Arch. Biochem. Biophys. 2010;501(1):6-15.

DOI: 10.1016/j.abb.2010.04.012. (PMID: 20417175)

5. WHO/FAO Diet, nutrition and the prevention of chronic diseases. Report of the joint WHO/FAO expert consultation. WHO Technical Report Series, No. 916 (TRS 916). 2003;160.

Available:http://www.who.int/dietphysicalac tivity/publications/trs916/en/

6. Scott DL, Wolfe F, Huizinga TW. Rheumatoid arthritis. Lancet. 2010; 373(9664):659-72. DOI: 10.1016/S01406736(09)60008-8. (PMID: 20870100)

7. Klareskog L, Catrina A I, Paget S. Rheumatoid arthritis. Lancet. 2009; 373(9664):659-72. DOI: 10.1016/S01406736(09)60008-8. (PMID: 19157532).

8. Fan W, Zhou ZY, Huang X F, Bao CD, Du F. Deoxycytidine kinase promotes the migration and invasion of fibroblast-like synoviocytes from rheumatoid arthritis patients. Int J Clin Exp Pathol. 2013;6, 2733. PMID: 24294360. (PMID: 24294360)
9. Alamanos $\mathrm{Y}$, Drosos AA. Epidemiology of adult rheumatoid arthritis. Autoimmun Rev. 2005;4(3):130-6. PMID:15823498

10. Filipovic I, Walker D, Forster F, Curry, A. Quantifying the economic burden of productivity loss in rheumatoid arthritis. Rheumatology (Oxford). 2011;50(6): 1083-90.

DOI:10.1093/rheumatology/keq399.

(PMID: 21245074)

11. Silano V, Coppens $P$, Larrañaga-Guetaria A, Minghetti P, Roth-Ehrang R. Regulations applicable to plant food supplements and related products in the European Union. Food Funct. 2011;2(12): 710-9. DOI:10.1039/c1fo10105f.710. (PMID: 21997496).

12. Rao AV, Snyder DM. Raspberries and human health: a review. J. Agric. Food Chem. 2010;58(7):3871-83.

DOI: $10.1021 / \mathrm{jf} 903484 \mathrm{~g}$.

(PMID: 20178390)

13. Figueira ME, et al. Chemical characterization of a red raspberry fruit extract and evaluation of its pharmacological effects in experimental models of acute inflammation and collagen-induced arthritis. Food Funct. 2014;5(12):3241-51.

DOI: $10.1039 / \mathrm{c} 4 \mathrm{fo} 00376 \mathrm{~d}$.

(PMID: 25322288)

14. Directive 2002/46/EC of the European Parliament and of the Council of 10 June 2002 on the approximation of the laws of the Member States relating to food supplements (Text with EEA relevance) OJ L 183, 12.7. 2002;51-57.

Available:http://eur-lex.europa.eu/legalcontent/EN/TXT/?uri=uriserv:OJ.L .2002.1 83.01.0051.01.ENG

15. Decreto-Lei № 136/2003. Ministério da Agricultura, Desenvolvimento Rural e Pescas. Transpõe para a ordem jurídica nacional a Directiva n. 0 2002/46/CE, do Parlamento Europeu e do Conselho, de 10 de Junho, relativa à aproximação das legislações dos Estados membros respeitantes aos suplementos alimentares. DR N ․ํ 147/2003, SÉRIE I-A de 2003-0628, Ato da Série I.

Available:https://dre.pt/web/guest/pesquisa -avancada/-

lasearch/advanced/maximized?types=SER IEl\&tipo=Decretolei\&numero $=136 \% 2 F 2003 \&$ search=Pesqui sar\&p

auth $=$ qEV c5G1J\&fpb=dHJ1ZQ\%3D\%3D 
16. Regulation (EC) No 178/2002 of the European Parliament and of the Council of 28 January 2002 laying down the general principles and requirements of food law, establishing the European Food Safety Authority and laying down procedures in matters of food safety OJ L 31. 2002;1-24. Available:http://eur-lex.europa.eu/legalcontent/EN/TXT/?uri=uriserv:OJ.L .2002.0 31.01.0001.01.ENG

17. European Parliament, Council. Corrigendum to Regulation (EC) No 1924/2006 of the European Parliament and of the Council of 20 December 2006 on nutrition and health claims made on foods (OJ L 404, 30. 12. 2006), OJ L 12. 2007; 3-18.

Available:http://eur-lex.europa.eu/legalcontent/EN/TXT/?uri=uriserv:OJ.L .2007.0 12.01.0003.01.ENG

18. European Commission; Consumers, D. H. a.; Food Law ed; 2015.

Available:http://ec.europa.eu/food/food/ind ex en.htm,

http://ec.europa.eu/nuhclaims/?event=sear ch\&CFID $=1872521 \&$ CFTOKEN=6f80000a 05fae154-D9155C69-D203-C963-

C9E17D026C1946F9\&jsessionid $=9212 \mathrm{abc}$ 5f663cc8e05f720413c484c4e1614TR

19. Regulation (EC) No 1925/2006 of the European Parliament and of the Council of 20 December 2006 on the addition of vitamins and minerals and of certain other substances to foods. OJ L 404. 2006; 26-38

Available:http://eur-lex.europa.eu/legalcontent/EN/TXT/?uri=uriserv:OJ.L .2006.4 04.01.0026.01.ENG

20. Regulation (EC) No 258/97 of the European Parliament and of the Council of 27 January 1997 concerning novel foods and novel food ingredients. OJ L 43 . 1997;1-6.

Available:http://eur-lex.europa.eu/legalcontent/EN/TXT/?uri=uriserv:OJ.L .1997.0 43.01.0001.01.ENG

21. Consolidated version of the Treaty on the Functioning of the European Union OJ C 326. 2012;47-390.

Available:http://eur-

lex.europa.eu/collection/eu-

law/treaties.html

22. Regulation (EC) No 764/2008 of the European Parliament and of the Council of 9 July 2008 laying down procedures relating to the application of certain national technical rules to products lawfully marketed in another Member State and repealing Decision No 3052/95/EC (Text with EEA relevance). OJ L 218. 2008;2129.

Available:http://eur-lex.europa.eu/legalcontent/EN/TXT/?qid=1435340326811\&uri =CELEX:32008R0764

23. European Commission. Commission Working Document. Guidance document. The concept of 'lawfully marketed' in the Mutual Recognition Regulation (EC) No $764 / 2008 /^{*} \mathrm{COM} / 2013 / 0592$ final */ (16/08/2013).

Available:http://eur-lex.europa.eu/legalcontent/EN/TXT/?qid=1435340495684\&uri =CELEX:52013DC0592

24. European Commission. Report from the Commission to the Council and the European Parliament on the use of substances other than vitamins and minerals in food supplements. SEC (2008)2976, SEC (2008)2977. Brussels, 5.12.2008, COM (2008) 824 final. Available:http://eur-lex.europa.eu/legalcontent/EN/TXT/?qid=1435500374067\&uri =CELEX:52008DC0824

25. European Advisory Services. The use of substances with nutritional or physiological effect other than vitamins and minerals in food supplements. Study undertaken for DG SANCO, European Commission. (Service contract $\mathrm{nr}$ SANCO/2006/E4/018). 28 March 2007.

Available:http://ec.europa.eu/food/safety/la belling nutrition/supplements/index en.ht $\underline{m}$

26. Eussen SR, et al. Functional foods and dietary supplements: products at the interface between pharma and nutrition. J. Eur J Pharmacol. 2011;668(Suppl 1):S2-9. DOI: 10.1016/j.ejphar.2011.07.008.

(PMID: 21816140)

27. Regulation (EU) No 609/2013 of the European Parliament and of the Council of 12 June 2013 on food intended for infants and young children, food for special medical purposes, and total diet replacement for weight control and repealing Council Directive 92/52/EEC, Commission Directives 96/8/EC, 1999/21/EC, 2006/125/EC and 2006/141/EC, Directive 2009/39/EC of the European Parliament and of the Council and Commission Regulations (EC) No 41/2009 and (EC) No 953/2009 Text with EEA relevance OJ L 181. 2013;35-56. 
Available:http://eur-lex.europa.eu/legalcontent/EN/TXT/?qid=1440420563469\&uri =CELEX:32013R0609

28. Regulation (EU) No $1169 / 2011$ of the European Parliament and of the Council of 25 October 2011 on the provision of food information to consumers, amending Regulations (EC) No 1924/2006 and (EC) No 1925/2006 of the European Parliament and of the Council, and repealing Commission Directive 87/250/EEC, Council Directive 90/496/EEC, Commission Directive 1999/10/EC, Directive 2000/13/EC of the European Parliament and of the Council, Commission Directives 2002/67/EC and 2008/5/EC and Commission Regulation (EC) No 608/2004 Text with EEA relevance. OJ L 304. 2011;18-63.

Available:http://eur-lex.europa.eu/legalcontent/EN/TXT/?uri=uriserv:OJ.L .2011.3 04.01.0018.01.ENG

29. Commission Regulation (EC) No 353/2008 of 18 April 2008 establishing implementing rules for applications for authorisation of health claims as provided for in Article 15 of Regulation (EC) No 1924/2006 of the European Parliament and of the Council (Text with EEA relevance) OJ L 109. 2008; 11-16.

Available:http://eur-lex.europa.eu/legalcontent/EN/TXT/?uri=uriserv:OJ.L .2008.1 09.01.0011.01.ENG

30. EFSA Panel on Dietetic Products, Nutrition and Allergies (NDA); Guidance for applicants on health claims.

Available:http://www.efsa.europa.eu/en/nd a/ndaguidelines

31. EFSA Panel on Dietetic Products, Nutrition and Allergies (NDA); Scientific and technical guidance for the preparation and presentation of an application for authorisation of a health claim (revision 1). EFSA Journal. 2011;9(5):2170. [36 pp.]. DOI: 10.2903/j.efsa.2011.2170.

Available: www.efsa.europa.eu/efsajournal

32. EFSA Panel on Dietetic Products, Nutrition and Allergies (NDA); General guidance for stakeholders on the evaluation of Article $13.1,13.5$ and 14 health claims. EFSA Journal 2011;9(4):2135. [24 pp.].

DOI: 10.2903/j.efsa.2011.2135.

Available: www.efsa.europa.eu/efsajournal

33. EFSA Panel on Dietetic Products, Nutrition and Allergies (NDA); Scientific Opinion on the substantiation of health claims related to gamma-linolenic acid and maintenance of joints (ID 494, 637, 1774, 2098), weight maintenance following weight loss (ID 496), maintenance of peripheral blood flow (ID 638), maintenance of normal blood pressure (ID 1771), maintenance of normal blood cholesterol concentrations (ID 1771) and maintenance of bone (ID 1774) pursuant to Article 13(1) of Regulation (EC) No 1924/2006. EFSA Journal. 2010; 8(2):1477. [21 pp.]. DOI: 10.2903/j.efsa. 2010.1477.

Available:www.efsa.europa.eu/efsajournal, (http://www.efsa.europa.eu/it/scdocs/doc/1 477.pdf)

34. EFSA Panel on Dietetic Products, Nutrition and Allergies (NDA); Scientific Opinion on the substantiation of health claims related to various food(s)/food constituent(s) claiming maintenance of joints (ID 1799, 1973, 2022, 2178, 2202, 2254, 2255, $2311,2394,2417,2418,2458,2649$, $2794,2798,3119,3144,3274,3283$, $3318,3339,3495,3511,3523,3555$, $3624,3699,3748,3770,3835,3884$, $3892,3904,3943,3978,4012,4020$, 4056, 4137, 4175), maintenance of bone (ID 1764, 1907, 2418, 4012, 4020, 4056, 4175) and maintenance of muscles (ID 2254, 2311) pursuant to Article 13(1) of Regulation (EC) No 1924/2006. EFSA Journal. 2010;8(2):1493. [22 pp.].

DOI: 10.2903/j.efsa.2010.1493.

Available: www.efsa.europa.eu/efsajournal

35. EFSA Panel on Dietetic Products, Nutrition and Allergies (NDA); Scientific Opinion on the substantiation of health claims related to zinc and function of the immune system (ID 291, 1757), DNA synthesis and cell division (ID 292, 1759), protection of DNA, proteins and lipids from oxidative damage (ID 294, 1758), maintenance of bone (ID 295, 1756), cognitive function (ID 296), fertility and reproduction (ID 297, 300), reproductive development (ID 298), muscle function (ID 299), metabolism of fatty acids (ID 302), maintenance of joints (ID 305), function of the heart and blood vessels (ID 306), prostate function (ID 307), thyroid function (ID 308), acid-base metabolism (ID 360), vitamin A metabolism (ID 361) and maintenance of vision (ID 361) pursuant to Article 13 of Regulation (EC) No 1924/2006 on request from European Commission. EFSA Journal. 2009; 7(9):1229. [34 pp.].

DOI: 10.2903/j.efsa.2009.1229. 
Available:www.efsa.europa.eu/efsajournal. (http://www.efsa.europa.eu/en/scdocs/doc/ 1229.pdf)

36. EFSA Panel on Dietetic Products, Nutrition and Allergies (NDA); Scientific Opinion on the substantiation of a health claim related to glucosamine and maintenance of normal joint cartilage pursuant to Article 13(5) of Regulation (EC) No 1924/2006. EFSA Journal. 2012;10(5):2691. [20 pp.].

DOI: 10.2903/j.efsa.2012.2691.

Available:www.efsa.europa.eu/efsajournal. (http://www.efsa.europa.eu/en/search/doc/ 2691.pdf)

37. EFSA Panel on Dietetic Products, Nutrition and Allergies (NDA); Scientific Opinion on the substantiation of health claims related to gamma-linolenic acid and maintenance of joints (ID 494, 637, 1774, 2098), weight maintenance following weight loss (ID 496), maintenance of peripheral blood flow (ID 638), maintenance of normal blood pressure (ID 1771), maintenance of normal blood cholesterol concentrations (ID 1771) and maintenance of bone (ID 1774) pursuant to Article 13(1) of Regulation (EC) No 1924/2006. EFSA Journal. 2010; 8(2):1477. [21 pp.].

doi: 10.2903/j.efsa.2010.1477.

Available:www.efsa.europa.eu. (http://www.efsa.europa.eu/it/scdocs/doc/1 477.pdf)

38. EFSA Panel on Dietetic Products, Nutrition and Allergies; Scientific Opinion on the substantiation of a health claim related to collagen hydrolysate and maintenance of joints pursuant to Article 13(5) of Regulation (EC) No 1924/2006. EFSA Journal 2011;9(7):2291. [11 pp.].

DOI: 10.2903/j.efsa.2011.2291.

Available: www.efsa.europa.eu/efsajournal (http://www.efsa.europa.eu/fr/efsajournal/d oc/2291.pdf)

39. European Food Safety Authority; Outcome of a public consultation on the Draft Opinion of the EFSA Panel on Dietetic Products, Nutrition, and Allergies (NDA) on a guidance on the scientific requirements for health claims related to bone, joints, skin, and oral health. Supporting Publications 2012:281. [64 pp.].

Available: www.efsa.europa.eu

40. EFSA Panel on Dietetic Products, Nutrition and Allergies (NDA); Scientific Opinion on the substantiation of health claims related to boron and maintenance of bone (ID 218, 219) and maintenance of joints (ID 219 ,
220) pursuant to Article 13(1) of Regulation (EC) No 1924/2006 on request from the European Commission. EFSA Journal. 2009;7(9):1261. [16 pp.].

DOI: 10.2903/j.efsa.2009.1261.

Available:www.efsa.europa.eu. (http://www.efsa.europa.eu/en/scdocs/doc/ 1261.pdf)

41. EFSA Panel on Dietetic Products, Nutrition and Allergies (NDA); Scientific Opinion on the substantiation of health claims related to methylsulfonylmethane alone or in combination with glucosamine hydrochloride and maintenance of joints (ID 395, 1616, 1617) pursuant to Article 13(1) of Regulation (EC) No 1924/2006 on request from the European Commission. EFSA Journal. 2009;7(9):1268. [15 pp.].

DOI: 10.2903/j.efsa.2009.1268.

Available:www.efsa.europa.eu. (http://www.efsa.europa.eu/de/scdocs/doc/ 1268.pdf)

42. EFSA Panel on Dietetic Products, Nutrition and Allergies (NDA); Scientific Opinion on the substantiation of a health claim related to Cynatine $\AA$ and maintenance of normal joint mobility pursuant to Article 13(5) of Regulation (EC) No 1924/2006. EFSA Journal. 2012;10(12):3004. [9 pp.].

DOI: 10.2903/j.efsa.2012.3004.

Available: www.efsa.europa.eu/efsajournal (http://www.efsa.europa.eu/it/search/doc/3 004.pdf)

43. EFSA Panel on Dietetic Products, Nutrition and Allergies (NDA); Scientific Opinion on the substantiation of a health claim related to EffEXT'M and "helps to support joint function by maintaining low levels of plasma C-reactive protein" pursuant to Article $13(5)$ of Regulation (EC) No 1924/2006. EFSA Journal. 2012;10(9): 2889. [6 pp.].

DOI: 10.2903/j.efsa.2012.2889.

Available: www.efsa.europa.eu/efsajournal

44. Deutsch L. Evaluation of the effect of Neptune Krill Oil on chronic inflammation and arthritic symptoms. Journal of the American College of Nutrition. 2007;26(1): 39-48. PMID: 17353582.

45. EFSA Panel on Dietetic Products, Nutrition and Allergies (NDA); Scientific Opinion on the substantiation of health claims related to various food(s)/food constituents(s) and "immune function/immune system" (ID 433, $605,645,791,1384,1451,1624,1743$, $1776,1838,1851,1854,1891,1895$, $3074,3191,3211,3218,3336,3341$, 
$3450,3514,3658,3756,3802,38053841$, 3935 , 3979), "contribution to body defences against external agents" (ID $2344,3208,3213,3270,3278,3285$, $3294,3309,3387,3424,3428,3536$, $3537,3539,3575,3577,3579,3582$, $3603,3618,3755,3776,3777,3778$, $3801,3804,3840,4367,4472$ ), reduction of inflammation (ID 1327, 1391) and decreasing potentially pathogenic gastrointestinal microorganisms (ID 2362, 2730, 4064) pursuant to Article 13(1) of Regulation (EC) No 1924/2006. EFSA Journal 2010;8(10):1799. [28 pp.].

DOI: 10.2903/j.efsa.2010.1799.

Available:www.efsa.europa.eu/efsajournal. htm

46. $\overline{E F S A}$ Panel on Dietetic Products, Nutrition and Allergies (NDA); Scientific Opinion on the substantiation of health claims related to vitamin $\mathrm{C}$ and protection of DNA, proteins and lipids from oxidative damage (ID 129, 138, 143, 148), antioxidant function of lutein (ID 146), maintenance of vision (ID 141, 142), collagen formation (ID $130,131,136,137,149)$, function of the nervous system (ID 133), function of the immune system (ID 134), function of the immune system during and after extreme physical exercise (ID 144), non-haem iron absorption (ID 132, 147), energy-yielding metabolism (ID 135), and relief in case of irritation in the upper respiratory tract (ID $1714,1715)$ pursuant to Article 13(1) of Regulation (EC) No 1924/2006 on request from the European Commission. EFSA Journal. 2009; 7(9):1226. [28 pp.].

DOI: 10.2903/j.efsa.2009.1226.

Available:www.efsa.europa.eu (http://www.efsa.europa.eu/en/scdocs/doc/ 1226.pdf)

47. Jean-Gilles D, et al. Anti-inflammatory effects of polyphenolic-enriched red raspberry extract in an antigen-induced arthritis rat model. J. Agric. Food Chem. 2012;60(23):5755-62.

DOI: $10.1021 / \mathrm{jf} 203456 \mathrm{w}$.

(PMID: 22111586)

48. Dawson J, et al. Epidemiology of hip and knee pain and its impact on overall health status in older adults. Rheumatology (Oxford). 2004;43(4):497-504. (PMID: 14762225).

49. Bruyère $\mathrm{O}$, et al. Health claims assessment in the field of joint and cartilage: a consensus viewpoint of the Group for the Respect of Ethics and
Excellence in Science. Curr Med Res Opin. 2012;28(4):611-6.

DOI:10.1185/03007995.2012.674934.

(PMID: 22404901)

50. EFSA Panel on Dietetic Products, Nutrition and Allergies (NDA); Scientific Opinion on the substantiation of health claims related to polyphenols in olive and protection of LDL particles from oxidative damage (ID 1333, 1638, 1639, 1696, 2865), maintenance of normal blood HDLcholesterol concentrations (ID 1639), maintenance of normal blood pressure (ID 3781), "anti-inflammatory properties" (ID 1882), "contributes to the upper respiratory tract health" (ID 3468), "can help to maintain a normal function of gastrointestinal tract" (3779), and "contributes to body defences against external agents" (ID 3467) pursuant to Article $13(1)$ of Regulation (EC) No 1924/2006. EFSA Journal. 2011;9(4):2033 [25 pp.].

DOI: 10.2903/j.efsa.2011.2033.

Available: www.efsa.europa.eu/efsajournal

51. Pravilnik o tvarima koje mogu biti dodan u hranu i uporabu u hrani i tvari čija uporaba u hrani zabranjen ili ograničen (NN 160/2013).

Available: http://www.digured.hr/

52. EFSA NDA Panel (EFSA Panel on Dietetic Products, Nutrition and Allergies), 342015. Draft general scientific guidance for stakeholders on health claim applications. EFSA Journal. 35 20YY; volume (issue): NNNN, $29 \mathrm{pp}$.

DOI: 10.2903/j.efsa.20YY.NNNN

53. EFSA Panel on Dietetic Products, Nutrition and Allergies (NDA); Scientific Opinion on the substantiation of a health claim related to EffEXTTM and "helps to support joint function by maintaining low levels of plasma C-reactive protein" pursuant to Article 13(5) of Regulation (EC) No 1924/2006. EFSA Journal 2012;10(9): 2889. [6 pp.].

DOI:10.2903/j.efsa.2012.2889.

Available: www.efsa.europa.eu/efsajournal (http://www.efsa.europa.eu/it/search/doc/2 889.pdf)

54. EFSA Panel on Dietetic Products, Nutrition and Allergies (NDA); Scientific Opinion on the substantiation of a health claim related to krill oil and maintenance of joint comfort pursuant to Article 13(5) of Regulation (EC) No 1924/2006. EFSA Journal 2012;10(12):3003. [9 pp.]. 
DOI: 10.2903/j.efsa.2012.3003.

Available:www.efsa.europa.eu/efsajournal. (http://www.efsa.europa.eu/fr/search/doc/3 003.pdf)

55. European Commission. Directive 2001/83/CE of the European Parliament and of the Council of 6 November 2001 on the Community code relating to medicinal products for human use. OJ L 311 , 28.11.2001;67-128.

Available: http://eur-lex.europa.eu/legalcontent/EN/TXT/?qid=1435660992470\&uri =CELEX:32001L0083

56. European Commission. Commission Directive 1999/83/EC of 8 September 1999 amending the Annex to Council Directive $75 / 318 /$ EEC on the approximation of the laws of the Member States relating to analytical, pharmacotoxicological and clinical standards and protocols in respect of the testing of medicinal products (Text with EEA relevance). OJ L 243. 1999; 9-11.

Available:http://eur-lex.europa.eu/legalcontent/EN/TXT/?qid=1435661108580\&uri =CELEX:31999L0083

57. European Commission. Directive 2004/24/EC of the European Parliament and of the Council of 31 March 2004 amending, as regards traditional herbal medicinal products, Directive 2001/83/EC on the Community code relating to medicinal products for human use. OJ $\mathrm{L}$ 136. 2004;85-90.

Available:http://eur-lex.europa.eu/legalcontent/EN/TXT/?qid=1435661233961\&uri =CELEX:32004L0024

58. De Boer A, Vos E, Bast A. Implementation of the nutrition and health claim regulation - the case of antioxidants. Regul Toxicol Pharmacol. 2014;68(3):475-87.

DOI: 10.1016/j.yrtph.2014.01.014.

(PMID: 24525062).

59. Binnendijk K, Rijkers $\mathrm{G}$. What is a health benefit? An evaluation of EFSA opinions on health benefits with reference to probiotics. Benef Microbes. 2013; 4(3): 223-30. DOI: 10.3920/BM2013.0019. (PMID: 23685375)
60. Donovan SB, Gibson G, Sanders M. Establishing and evaluating health claims for probiotics. Adv Nutr. 2012;3(5):723-5. DOI: 10.3945/an.112.002592.

(PMID: 21396470)

61. European Commission. Discussion paper on health claims on botanicals used in foods; 2012.

Available:http://izbamleka.pl/wpcontent/uploads/2012/09/instrukcja.pdf

62. Malthioudakis, B. European Commission. Presentation in the International Conference - Botanicals in Food Supplements BELFRIT, Rome, 18 April 2013.

Available:http://www.salute.gov.it/imgs/C 1 7 EventiStampa 163 intervisteRelatori it emlnterviste 8 fileAllegatolntervista.pdf

63. European Food Safety Authority; Outcome of a public consultation on the Draft Opinion of the EFSA Panel on Dietetic Products, Nutrition, and Allergies (NDA) on a guidance on the scientific requirements for health claims related to bone, joints, skin, and oral health. Supporting Publications. 2012:281. [64 pp.].

Available: www.efsa.europa.eu

64. Jordan JM, et al. Methodologic issues in clinical trials for prevention or risk reduction in osteoarthritis. Osteoarthritis Cartilage. 2011;19(5):500-8.

DOI: 10.1016/j.joca.2010.10.031. (PMID: 22983853).

65. European Commission. Directive 2001/20/EC of the European Parliament and of the Council of 4 April 2001 on the approximation of the laws, regulations and administrative provisions of the Member States relating to the implementation of good clinical practice in the conduct of clinical trials on medicinal products for human use. OJ L 121. 2001;34-44. Available:http://eur-lex.europa.eu/legalcontent/EN/TXT/?uri=uriserv:OJ.L .2001.1 21.01.0034.01.ENG

66. Richardson DP. Preparing dossiers: strength of the evidence and problems of proof. Proc Nutr Soc. 2012;71(1):127-40. DOI: $10.1017 / S 002966511100317 \mathrm{X}$. (PMID:21939590).

(C) 2016 Bettencourt-Câmara et al.; This is an Open Access article distributed under the terms of the Creative Commons Attribution License (http://creativecommons.org/licenses/by/4.0), which permits unrestricted use, distribution, and reproduction in any medium, provided the original work is properly cited. 